Journal of Marine Systems

March 2017, Volume 167, Pages 55-67

http://dx.doi.org/10.1016/i.jmarsys.2016.10.013

http://archimer.ifremer.fr/doc/00355/46642/

(c) 2016 Elsevier B.V. All rights reserved.

\title{
A coupled biophysical model for the distribution of the great scallop Pecten maximus in the English Channel
}

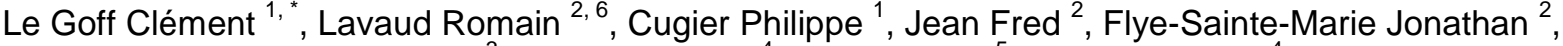 \\ Foucher Eric ${ }^{3}$, Desroy Nicolas ${ }^{4}$, Fifas Spyros ${ }^{5}$, Foveau Aurélie ${ }^{4}$
}

1 IFREMER, Ctr Bretagne, DYNECO-LEBCO, CS10070, F-29280 Plouzané, France

${ }^{2}$ Université de Bretagne Occidentale, Institut Universitaire Européen de la Mer, Laboratoire des

Sciences de L'Environnement Marin (LEMAR UMR CNRS 6539), Rue Dumont d'Urville, 29280

Plouzané, France

${ }^{3}$ IFREMER, Ctr Manche Mer-du-Nord, Laboratoire de Ressources Halieutiques, F-14520 Port en

Bessin, France

${ }^{4}$ IFREMER, Ctr Bretagne, Laboratoire Environnement Ressources Bretagne nord, F-35801 Dinard, France

${ }^{5}$ IFREMER, Ctr Bretagne, Laboratoire de Biologie Halieutique, CS 10070, F-29280 Plouzané, France

${ }^{6}$ Department of Fisheries and Oceans, Gulf Fisheries Centre, Science Branch, P.O. Box 5030,

Moncton, NB E1C 9B6, Canada

* Corresponding author : Clément Le Goff, email address : cllegoff@ifremer.fr

\begin{abstract}
:
In this paper we used a modelling approach integrating both physical and biological constraints to understand the biogeographical distribution of the great scallop Pecten maximus in the English Channel during its whole life cycle. A 3D bio-hydrodynamical model (ECO-MARS3D) providing environmental conditions was coupled to (i) a population dynamics model and (ii) an individual ecophysiological model (Dynamic Energy Budget model). We performed the coupling sequentially, which underlined the respective role of biological and physical factors in defining $P$. maximus distribution in the English Channel. Results show that larval dispersion by hydrodynamics explains most of the scallop distribution and enlighten the main known hotspots for the population, basically corresponding to the main fishing areas. The mechanistic description of individual bioenergetics shows that food availability and temperature control growth and reproduction and explain how populations may maintain themselves in particular locations. This last coupling leads to more realistic densities and distributions of adults in the English Channel. The results of this study improves our knowledge on the stock and distribution dynamics of $P$. maximus, and provides grounds for useful tools to support management strategies.
\end{abstract}




\section{Highlights}

- A deterministic modelling of Pecten maximus in the English Channel - Hierarchisation of major processes explaining $P$. maximus distribution Larval dispersion by hydrodynamic Population dynamic model structured in age Modelling of individual growth and fecundity in relation to environmental conditions

Keywords: Population dynamic model, Ecophysiological model, English Channel, Pecten maximus, Spatial distribution

\section{Introduction}

The great scallop Pecten maximus is exploited all along its distribution range, from Norway to Portugal. Fisheries are mostly located in the English Channel, where $P$. maximus is the most abundantly harvested species in terms of landings (in biomass and in value) for the French inshore fleet. Considering its broad distribution and its high economic value, several studies have been conducted on the biology and life history traits of this species (Mason, 1957; Antoine, 1979; Le Pennec et al., 2003; Brand, 2006; Cragg, 2006; Thompson and MacDonald, 2006). 
The great scallop is a meroplanktonic hermaphrodite species, spending a small part of its development in the water column (as larvae) and the major part of its life on the sea floor. The mechanisms providing suitable environmental conditions for the settlement and the development of $P$. maximus have yet to be considered simultaneously to determine the potential for survival and growth of individuals in a given habitat. As they are difficult to carry out, numerical models dealing with the whole life cycle of species are uncommon (Possingham and Roughgarden, 1990; Dekshenieks et al., 2000; Klinck et al., 2002; Savina and Ménesguen, 2008). Studies focus either on the larval dispersion modelling (for example: Young et al., 1998; Ellien et al., 2004; Condie et al., 2006; Bidegain et al. 2013, Nicolle et al. 2013), or on the population dynamics of the benthic stage (McArdle et al., 1997; Solidoro et al., 2003; Gangnery et al., 2004). Distribution of benthic marine species is driven by numerous abiotic (hydrodynamics, sediment type, etc.) and biotic (individual physiology characteristics, ecological interactions) factors. If growth, fecundity and mortality are known to be related to physiological state and food availability, they also depend on predation, trophic competition and physiological stress. Coupling the environment (temperature, hydrodynamics, food availability) to the entire life cycle of $P$. maximus is essential to correctly understand the bio-geographical distribution of the species.

The present study is based on the use and coupling of three models: 1) the hydrodynamic MARS3D model (Model for Applications at Regional Scale, Lazure and Dumas, 2008) used to compute the physical characteristics prevailing in the English Channel (temperature, salinity, tide, current velocities) was coupled to a NPZD (Nutrient-Phytoplankton-Zooplankton-Detritus) primary production model (giving the ECO-MARS3D model) in order to simulate the biological properties of the ecosystem (particularly chlorophyll- $a$ as a food proxy for scallops); 2) a population dynamic model developed for P. maximus, describing the whole life cycle (planktonic and benthic stages) using a mechanistic approach (based on Savina and Ménesguen, 2008) and 3) an ecophysiological model based on the Dynamic Energy Budget (DEB) theory (Kooijman, 2010) adapted to $P$. maximus (Lavaud et al., 2014) to simulate individual growth, fecundity and physiological status. The present paper describes the coupling of these models to describe the biogeography of the great scallop in the English Channel. The simulated spatialized abundances are discussed regarding in situ data, which are limited to presence of $P$. maximus and landings from French and UK fleets in the English Channel.

\section{Materials and methods}

\subsection{General description of the study area}

The English Channel is part of the Northwest European Continental shelf and separates the Atlantic Ocean from the North Sea. Its western boundary is approximately represented by the longitudinal line crossing the Scilly Islands seaward from the Cornish coast in the UK and the eastern boundary is defined by the Strait of Dover (Figure 1). The Channel is characterized by a macrotidal regime, which leads to strong tidal currents and a high tidal range, a complex gyre system around the Islands of Jersey and Guernsey (Normand-Breton gulf) and a general residual circulation from west to east, driving water from the Atlantic to the North Sea (Salomon et Breton., 1993). The eastern part of the Channel receives strong fresh water input, mainly coming from the Seine River (mean flow about $500 \mathrm{~m}^{3} \mathrm{~s}^{-1}$ ). The Seine River brings nutrients to the Bay of Seine and more generally the eastern Channel, occasionally leading to eutrophic conditions resulting in phytoplankton proliferation, toxic blooms, etc. (Cugier et al., 2005; Romero et al., 2013; Passy et al., 2016).

High species richness and abundance of benthic fauna is encountered in the English Channel (Holme, 1966; Cabioch, 1968; Gentil, 1976; Cabioch et al., 1977; Retière, 1979) that has favored the development of many fisheries including the great scallop. However, precise knowledge of its distribution and abundance in the English Channel is still lacking. Available data are mostly qualitative (Figure 2), except in the two major areas of the French fishery: the bays of Seine and of 
Saint-Brieuc (see Figure 1) where average stock assessments are between 6000 and 8000 tons, respectively, for the year 2012. Nevertheless, observed landing values could give a proxy of the real biomass distribution (Figure 3). This species is heavily harvested and despite the significance of the great scallop fishery in the English Channel, there is no regulation system at the European level to date (Foucher and Fifas 2015).

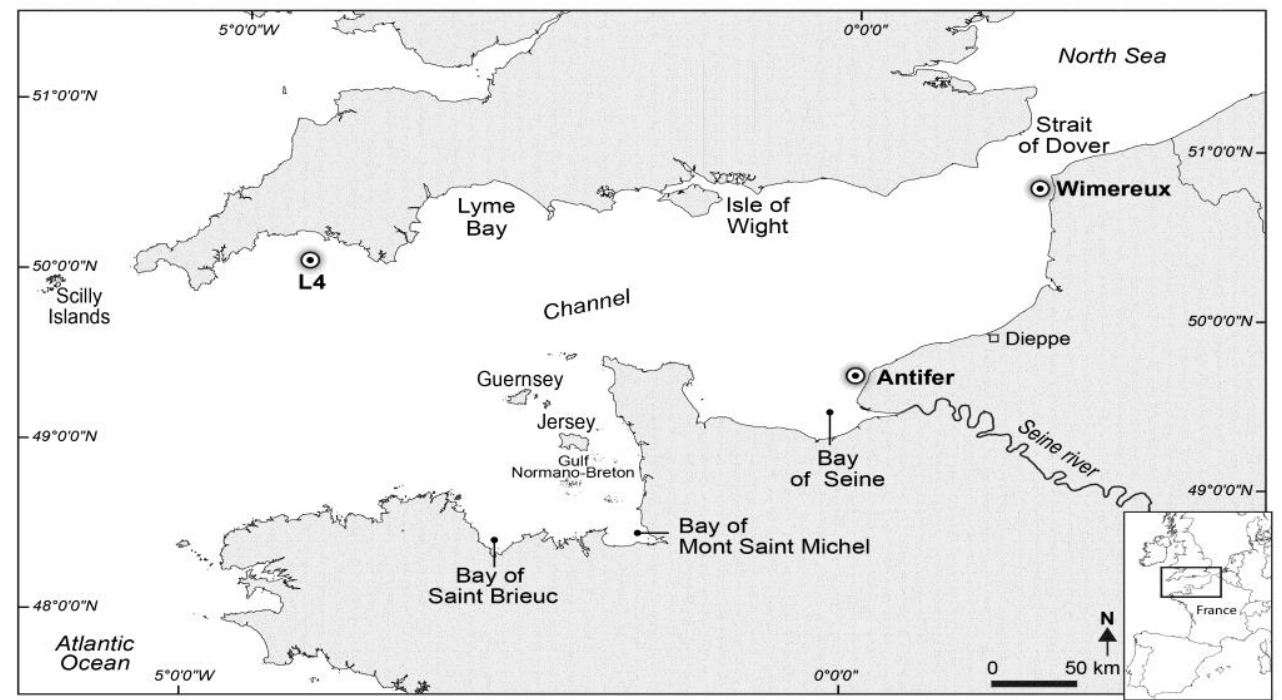

Figure 1. Studied area in the English Channel (All the locations cited in the text are clearly shown). $\odot$ Locations of time series environmental data for ecosystem model validation (L4, Antifer, Wimereux).

\subsection{Models}

\subsubsection{Hydrodynamical and biogeochemical models}

The three-dimensional (3D) hydrodynamic model MARS (Lazure and Dumas, 2008) was used to simulate physical properties in the study area. It is a finite difference, mode splitting model in a sigma-coordinate framework, here applied to the English Channel (from $47.88^{\circ} \mathrm{N}$ to $51.15^{\circ} \mathrm{N}$ in latitude and from $-7.03^{\circ} \mathrm{W}$ to $3.00^{\circ} \mathrm{W}$ in longitude). The study area was divided in 2 by $2 \mathrm{~km}$ meshes to form a rectangular grid with a vertical resolution of 10 sigma layers. This hydrodynamic model allows computing current velocity, temperature and salinity fields. It was coupled to a NPZD primary production model used to simulate the dynamics of free-living plankton in the Channel (ECO-MARS3D).

This NPZD model is similar to the one previously developed for the same area by VanhoutteBrunier et al. (2008). The model integrates the nutrient cycles of nitrogen, phosphorus and silica and considers three phytoplanktonic compartments: diatoms, dinoflagelates and nanoflagelates expressed in the form of their nitrogen content (Figure 4). These three variables were converted into a single parameter expressed as chlorophyll- $a$ (chl- $a$ ) concentration and later used as a trophic source proxy for the great scallop (see http://wwz.ifremer.fr/mars3d/Le-modele/Descriptif/ for a complete description of the model and of the different modules). 

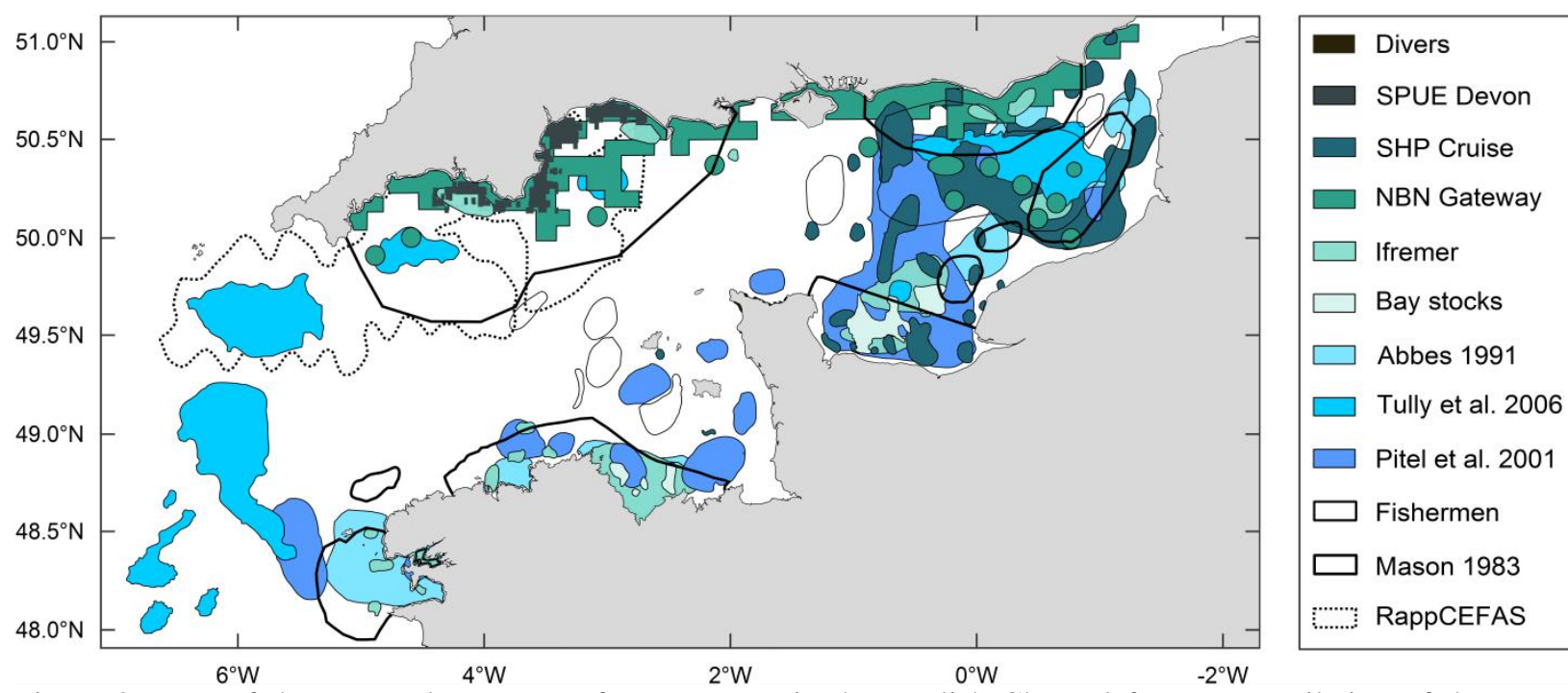

Figure 2. Map of the reported presence of P. maximus in the English Channel from a compilation of data sets and literature sources.

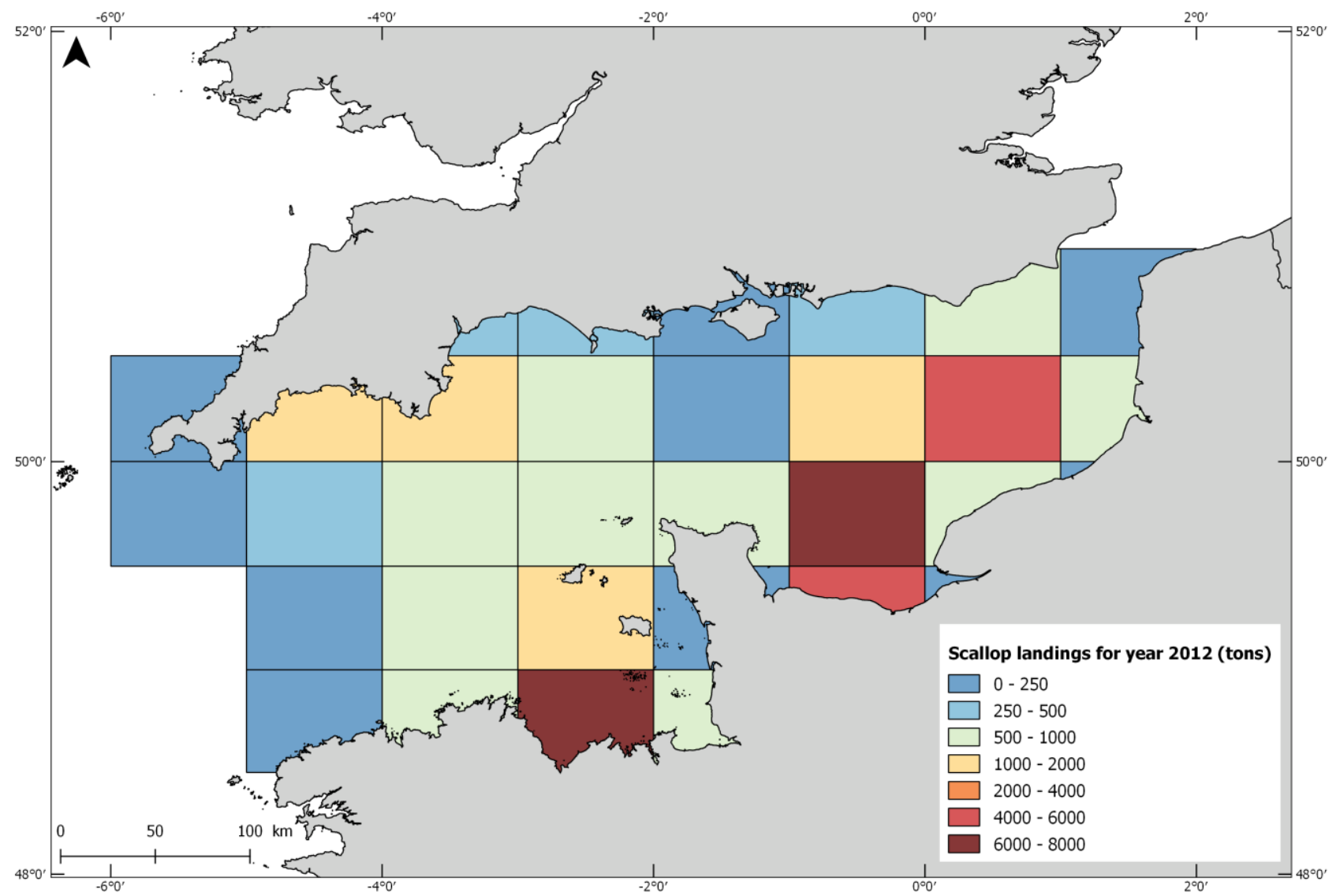

Figure 3. Pecten maximus landings from French and UK fleets in 2012. Landings are projected on the ICES statistical grid for English Channel. 


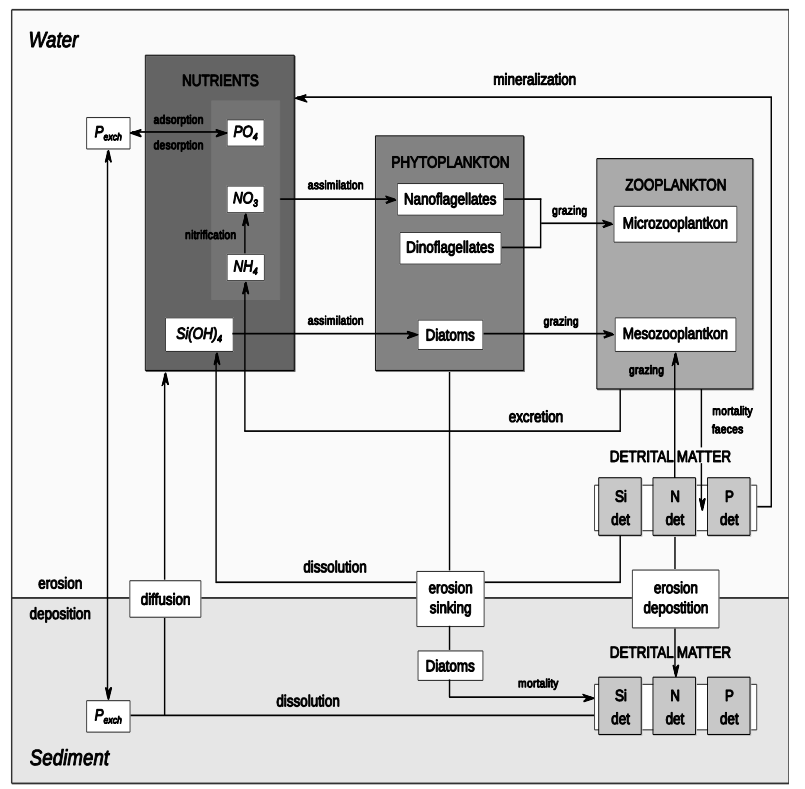

Figure 4. Conceptual scheme of the ECO-MARS3D model. Nutrient, phytoplankton and zooplankton are modelled to calculate primary production. Arrows represent the mechanisms (source and sink) that modified the concentration of the different constituents.

\subsubsection{The population dynamic model}

As most bivalve species, $P$. maximus presents a larval planktonic phase. After a dispersal period of approximately one month in the water column, larvae settle on the sea bottom to achieve metamorphosis. Then, great scallops spend the rest of their life in the benthic compartment with limited mobility. The modelling of population dynamics takes into account these two stages and is based on the model developed by Savina and Ménesguen (2008) for Paphia rhomboïdes (Figure 5). All the equations and parameters of the population dynamic model are detailed in Appendix 1 and 2. The main features are described below.

The adult benthic compartment was represented by twelve annual age classes, each being described by its abundance (ind. $\mathrm{m}^{-2}$ ). Individuals were therefore assumed to die at the end of their twelfth year. Abundance was computed as the result of three processes:

(1) Recruitment, i.e. the arrival of individuals from the previous age class at their birthday, the first age class (i.e. the youngest adults) corresponding to the arrival of recruited larvae;

(2) Mortality was computed as a negative exponential function, as young individuals are more vulnerable than older ones. This was adapted from Savina and Ménesguen (2008) who used a similar pattern related to weight. A density-dependent mortality formulation (Holm, 1990) was calculated as the product of $1 \%$ of the age dependent mortality by the sum of the individuals aged more than 2 years;

(3) Aging, i.e. the advancement of individuals to the next age class at their birthday. The transfer of individuals from one age class to another occurred every year instantaneously. This process starts from the oldest age class which is totally emptied (as all the oldest individuals die) and which then receives the individuals from the previous age class.

The spawning events were modelled using a Gaussian law and the amount of eggs released was determined as a mean for all individuals, according to species characteristics. Maturity is reached during the second year of development (Mason, 1957) and great scallops can produce up to 15 to 21 million eggs each year at the age of three and four, respectively (Le Pennec et al., 2003).

The pelagic larval compartment was represented by ten age classes of three days, which results in a total larval life cycle of 30 days. Each age class was described by the larval abundance in the water 
column (ind. $\mathrm{m}^{-3}$ ). The same processes that were applied to adults were considered to compute the larval abundance:

(1) Recruitment of individuals from the previous age class occurred every three days (including the arrival of freshly spawned larvae for the youngest age class);

(2) Mortality was fixed at $0.5 \mathrm{day}^{-1}$ during this life stage (Savina and Ménesguen 2008);

(3) Aging was considered the advancement of individuals to the next age class every three days creating ten age classes.

During the first half of their life, larvae drift in the water column where they are directed by currents. Once larvae reach the age of 15 days, a settling velocity of $10^{-4} \mathrm{~m} \mathrm{~s}^{-1}$ (Cragg and Crisp, 1991) was imposed to simulate their settlement on the bottom to recruit (and join the first adult age class). Larvae settlement in the model was also controlled by the water current velocity. Larvae remained in the water column as long as the flow stayed above a threshold value of $1 \mathrm{~m} \mathrm{~s}^{-1}$ and finally died if they were still in water column after 30 days.

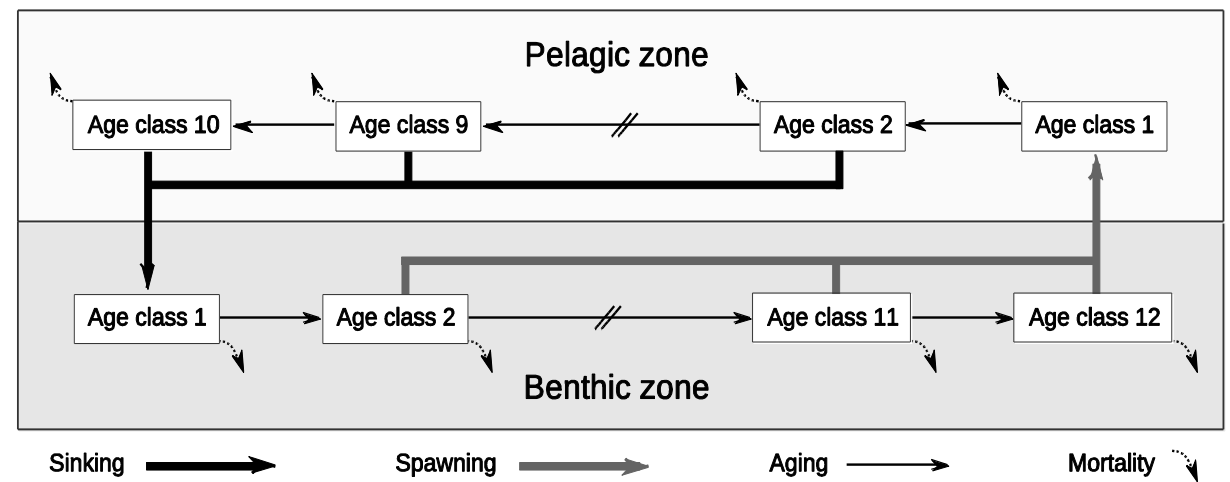

Figure 5. Structure of the population dynamic model (from Savina and Ménesguen, 2008). Pecten maximus life cycle is split into a benthic adult stage and pelagic larval stage, each being subdivided into age classes (12 and 10, respectively). The main processes of the population dynamics are illustrated by arrows (sinking, spawning, aging and mortality).

Parameters of the population dynamic model were kept constant in space and time and did not depend on environmental conditions. In particular, the number of eggs laid by mature adults was the same for all individuals older than 2 years, wherever they were located and was independent of the individual physiological status. All parameters are listed in Appendix 2.

\subsubsection{The individual growth model}

The individual growth model was based on the Dynamic Energy Budget theory (DEB; Kooijman 2010). DEB theory defines a framework wherein energy fluxes in individuals are modeled in a mechanistic and quantitative way to predict growth, reproduction and maintenance from a species specific set of parameters and environmental forcing factors, including temperature and a food proxy (Figure 6). The individual biomass consists of two compartments: structure and reserve, distinguished by their dynamics. Structure, or structural mass, is the mass of somatic tissues and requires maintenance. Reserve can be defined as the mass of compounds that can be mobilized for metabolic purposes and does not need maintenance. The state variables of the model are: the amount of energy in reserve $\mathrm{E}(\mathrm{J})$, the volume of structural mass $\mathrm{V}\left(\mathrm{cm}^{3}\right)$ and the reproduction buffer $E_{R}(J)$, corresponding to the fraction of reserve allocated to reproduction. Energy assimilated from food is converted with a constant efficiency into a reserve pool from which it is mobilized to fuel metabolism. Reserve dynamics are computed as the difference between assimilation flux and mobilization flux. A fixed proportion $(\kappa)$ of this mobilization flux is allocated to somatic growth plus its maintenance with priority to maintenance. The remaining fraction $(1-\kappa)$ is spent on development or reproduction, in juveniles and adults respectively, and maturity maintenance with priority to maintenance. Temperature controls every rate as a consequence of the Arrhenius law. The specific model for P. maximus, described by Lavaud et al. (2014), was used in this study to compute individual growth and reproduction. 


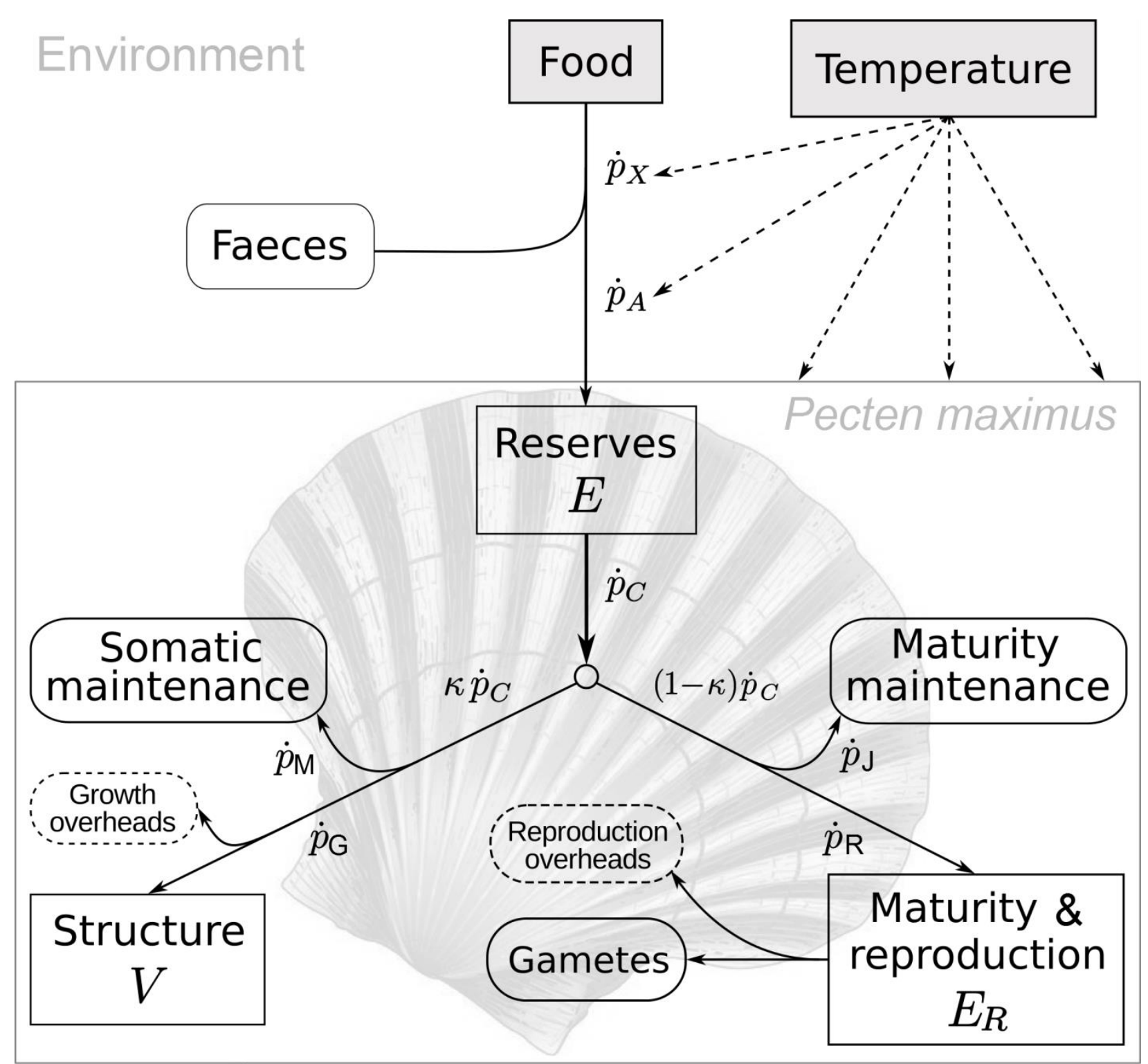

Figure 6. Conceptual scheme of the DEB model applied to P. maximus. Food and temperature are the forcing variables (gray boxes) and reserves $(\mathrm{E})$, structure $(\mathrm{V})$ and maturity/reproduction $\left(\mathrm{E}_{\mathrm{R}}\right)$, are the state variables (white boxes). Dark arrows show energy fluxes and dotted arrows indicate temperature's influence on these rates. (From Lavaud et al., 2014).

\subsubsection{Coupling the models}

These models have been coupled step by step in three ways: 1) the population dynamic model with the hydrodynamic of MARS3D model; 2) the DEB model with the primary production model ECOMARS3D; 3) the population dynamic model with the DEB model and the primary production model.

\subsubsection{Population dynamic model and MARS3D}

The aim of this first coupling was mainly to study the role of larval dispersion in the distribution of adults. The population model was coupled to the environment through hydrodynamics, to simulate larval dispersion and recruitment without considering trophic conditions or water temperature.

\subsubsection{Bioenergetic model and ECO-MARS3D}

The objective of this coupling was to use the outputs of the ECO-MARS3D model, food (chl- $a$ ) and 
temperature, as inputs for the individual DEB model. This approach provides information on the role played by trophic and temperature conditions on the distribution of the great scallop.

In the DEB model, energy that fuels all processes in the organism is taken from the food provided by the environment. Food availability was converted to an ingestion rate via a Holling type II functional response $\mathrm{f}$ written as: $\mathrm{f}=\mathrm{X} /\left(\mathrm{X}_{\mathrm{K}}+\mathrm{X}\right)$, where $\mathrm{X}$ is the food density in the environment and $\mathrm{X}_{\mathrm{K}}$ the half-saturation coefficient. The later was calibrated by adjusting the theoretical growth curve given by the DEB-model to an observed growth curve from the Bay of Seine. It was then applied to every point of the simulation.

In each $2 \times 2 \mathrm{~km}$ mesh of the English Channel, growth and egg production of $P$. maximus were simulated using the chl- $a$ and temperature time series computed in ECO-MARS3D. The result is a spatialized potential growth and egg production for each age class in the English Channel.

\subsubsection{Coupling ECO-MARS3D, population dynamics and DEB growth models}

Finally, the three models were used simultaneously. The coupling between the DEB model and ECO-MARS3D provided spatial and temporal information on the fecundity of mature adults for each age class. Therefore, the population dynamic model was no longer provided with a uniform fecundity in space and among age-classes, as in paragraph 2.2.4.1, but was directly linked to the trophic availability and temperature conditions.

\subsubsection{Boundary and initial conditions, simulation length}

In the MARS3D model, the bathymetry was provided by the French Navy Oceanographic Department (SHOM: Service Hydrographique et Océanographique de la Marine). River inputs (daily averaged flows and nutrient concentrations based on monthly or bimonthly measurements) came from French Water Agencies and UK Environment Agency and are available through the French oceanographic operational service (PREVIMER, see www.previmer.org). Concentrations at the seaward boundaries were taken from an operational model of the PREVIMER project. The freesurface elevation and currents at the open boundaries of the 3D model were provided off-line by a 2D barotropic model of greater geographic extent which covers the north-western European continental shelf.

Finally, at the ocean-atmosphere interface, meteorological data (air temperature, atmospheric pressure, air moisture, cloud cover, wind speed and direction) were provided by the meteorological model ARPEGE from Météo-France (French meteorological forecast department) with a $0.5^{\circ}$ spatial resolution and a six-hour temporal resolution.

The ECO-MARS3D model was run for seven years from 2000 to 2006, providing fields of environmental parameters (temperature, salinity, chlorophyll- $a$ and nutrients) and their variability.

The initial conditions of the population dynamic model were set by filling the whole sea channel with individuals of age class 3 at a concentration of 0.3 ind. $\mathrm{m}^{-2}$. Based on this initial condition, the evolution of the entire population was calculated over time until reaching a stabilization of the total number of individuals at the scale of the Channel.

\subsubsection{Evaluation of ECO-MARS3D outputs}

This paper does not intend to detail and validate the ecosystem model. Nevertheless, to ensure the ability of the ecosystem model to reproduce the main environmental characteristics and thus to validate the use of outputs, results were compared to available environmental observations in three locations of the Channel (see Figure 1): in the western Channel (data from station L4 monitored by Plymouth Marine Laboratory); in the Bay of Seine (data from Antifer station in the Seine River plume, monitored by Ifremer); and near the Dover Strait (at the eastern limit of the studied area, 
Temperature was correctly simulated by the model in the three locations of the Channel (Figure 7). Chl- $a$ reached very high levels (more than $40 \mu \mathrm{g} \mathrm{L}^{-1}$ ) in the enriched vicinity of the Seine River to medium/low levels at Wimereux and L4 stations and was also correctly represented by ECOMARS3D (Figure 7). Although temperature and chl- $a$ are the only variables used further in the coupling process, salinity and nutrient simulations were also assessed (not presented in this paper) as they are major parameters of the hydrodynamic and biological cycles.
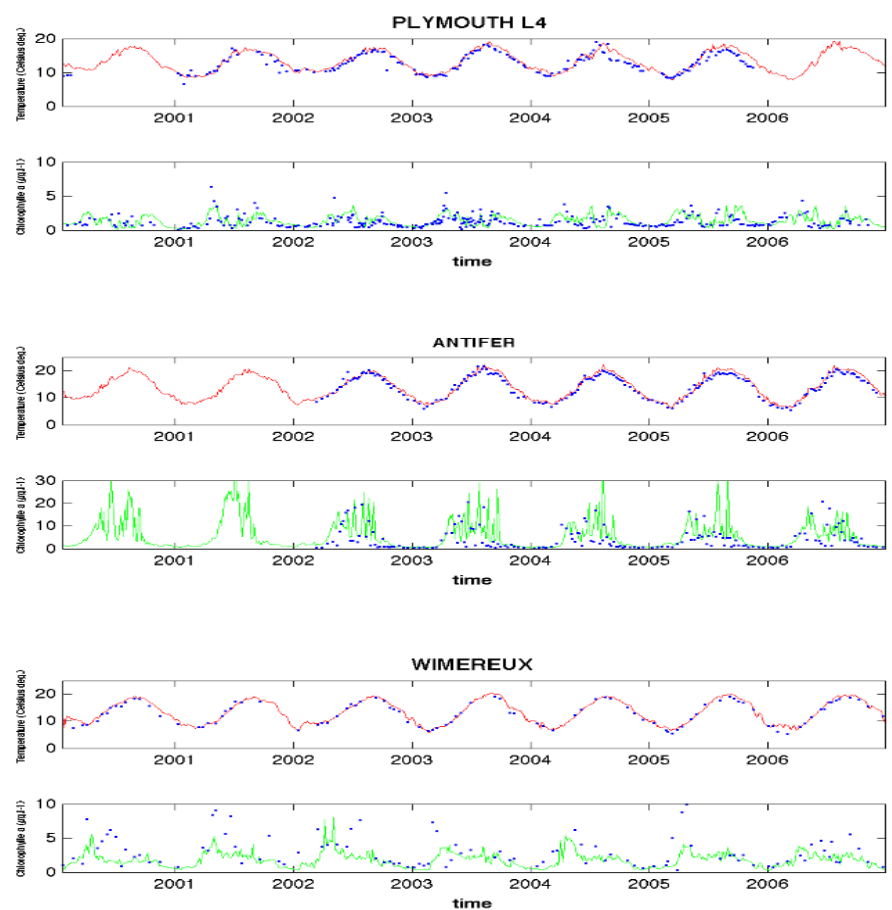

Figure 7. Comparison of measured (dots) and simulated (lines) temperature and chlorophyll- $a$ in three different locations of the English Channel (L4, Antifer and Wimereux).

\section{Results}

\subsection{Simulating $P$. maximus distribution in the Channel: the role of hydrodynamics}

The first simulation was run for 27 years to evaluate the physical aspect of the establishment of the population in the Channel. Despite a homogenous and unrealistic distribution of scallops in the initial condition, the population reached a stable state after 20 years, with the total number of individuals in the Channel remaining constant (Figure 8). High abundances were observed along the British coasts, in the Normand-Breton Gulf, in the Bay of Seine and in the eastern English Channel (Figure 8). 

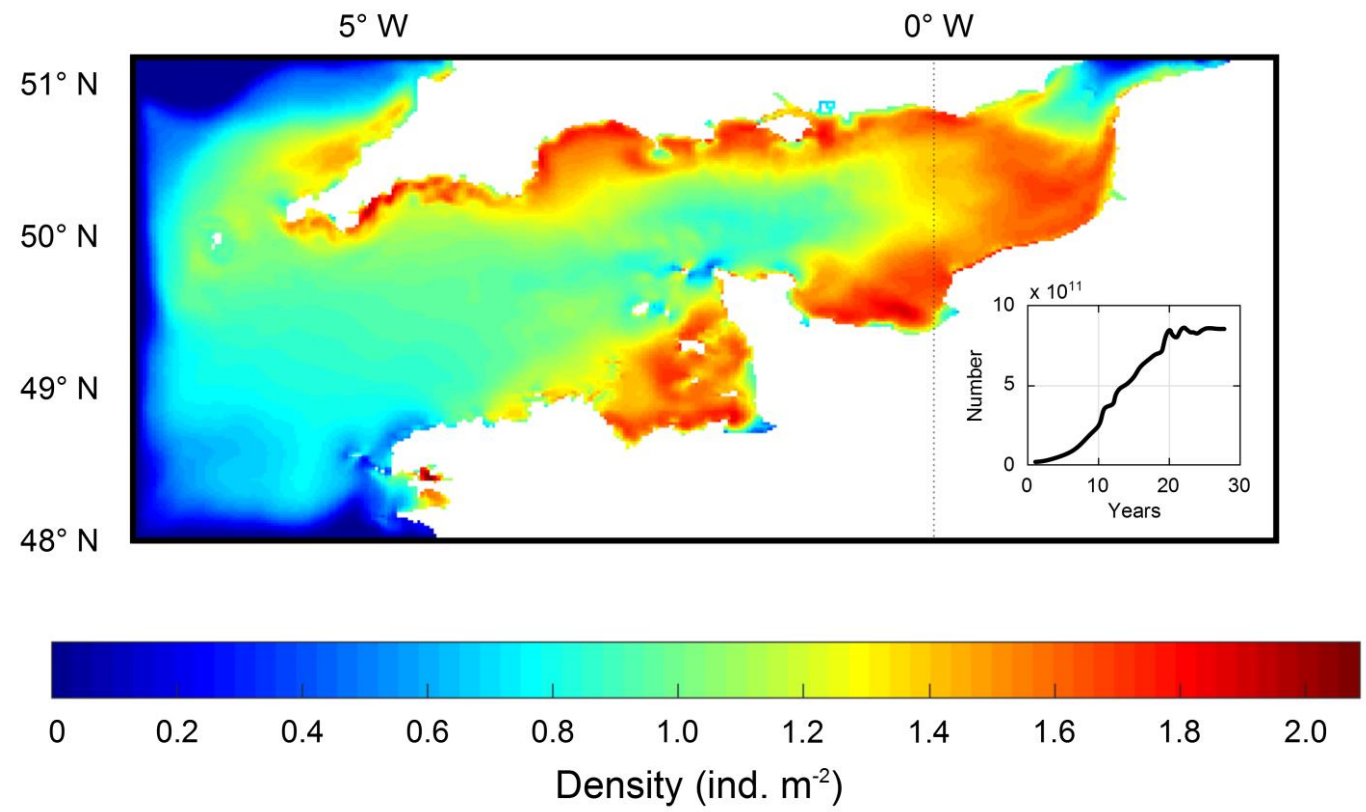

Figure 8. Distribution map of $P$. maximus population after 27 years of simulations as the total density of the individuals from age class 2 to age class 12. The lower right corner graph illustrates the dynamic stabilization over time of the $P$. maximus population in the English Channel. It represents the evolution of the total number of the individuals from age class 2 to age class 12 throughout the 27 years of simulation.

Lower densities were modeled in the center of the study area and in the western region as well as along the coast of Brittany where currents and/or depths are higher. The overall pattern is quite realistic compared to the map of observed presence (Figure 2). Nevertheless, simulated densities of 1.8 ind. $\mathrm{m}^{-2}$ in some broad areas seem to be largely overestimated.

\subsection{Potential growth and fecundity in the English Channel}

In the second step of the study, the individual physiological response was simulated in varying environmental conditions implemented through the ECO-MARS3D model. The map of potential length obtained after seven years of growth is shown in Figure 9. In this simulation, we represented the potential growth of an average individual in each part of the Channel, independently of the effective presence of scallops. An ultimate length of about $15 \mathrm{~cm}$ was consistently reached near the coast where food availability shows the highest concentrations (Figure 10). Although the map tends to indicate that scallops could grow pretty much everywhere in the Channel, lower growth rates were observed in the western part, leading to remarkably small individuals (under $8 \mathrm{~cm}$ after 7 years). 


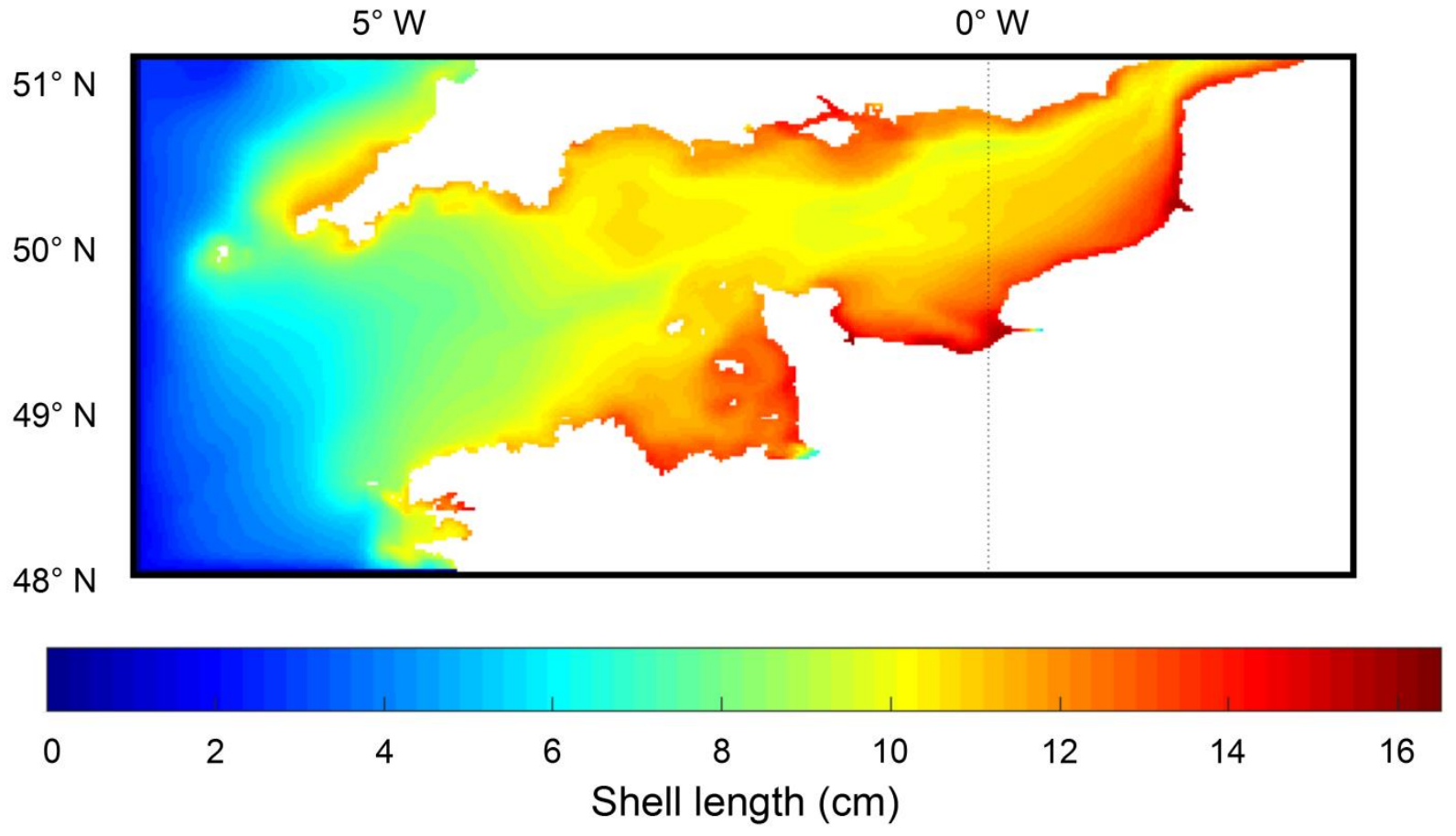

Figure 9. Predicted shell length $(\mathrm{cm})$ of $P$. maximus after 7 years of simulation using the DEB model, forced by modeled temperature and chlorophyll- $a$ from 2000 to 2006 (ECO-MARS3D).

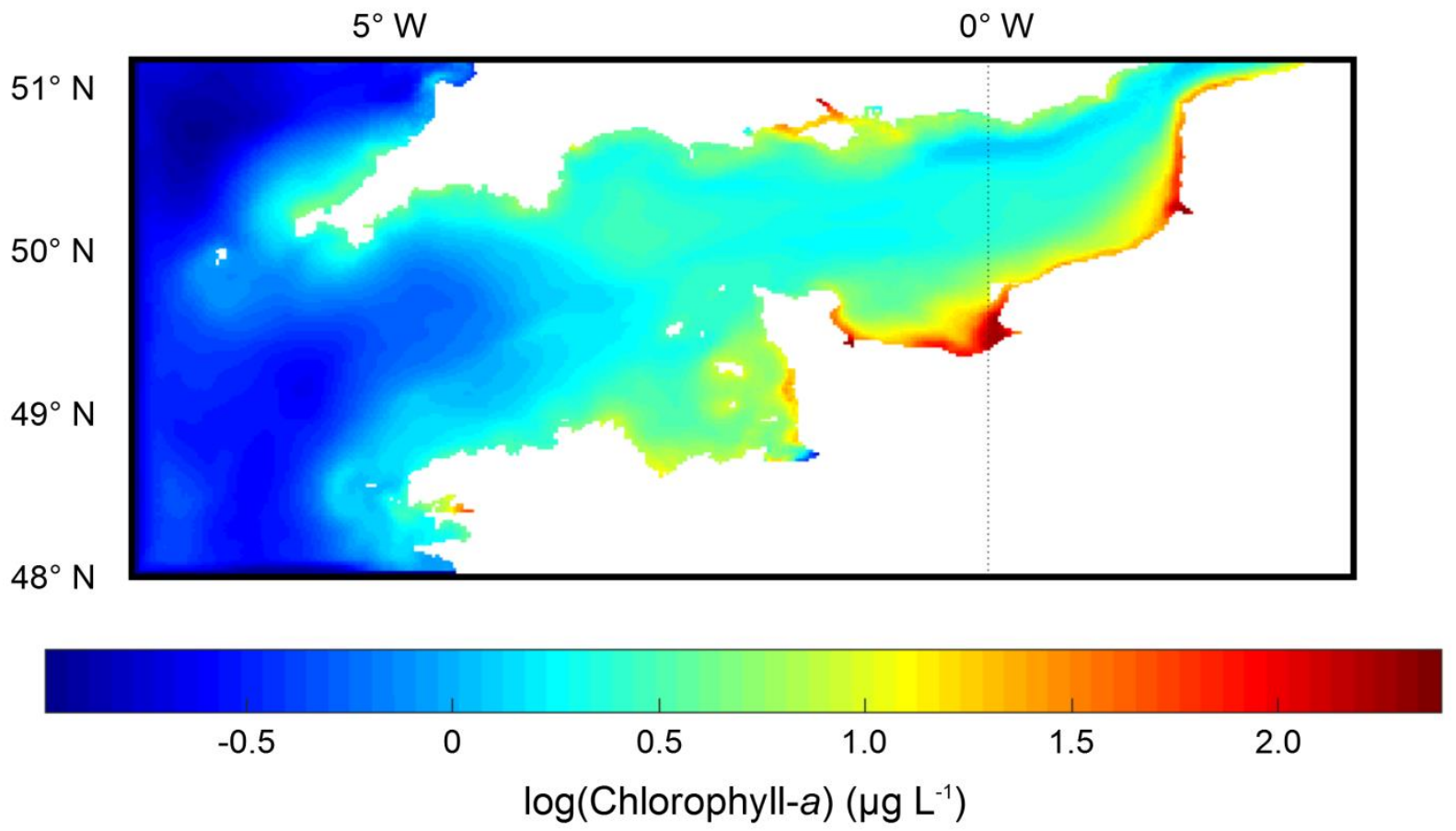

Figure 10. Modeled annual average chlorophyll- $a\left(\mu \mathrm{g} \mathrm{L}^{-1}\right)$ for year 2004.

To evaluate model output consistency, simulated growth curves were compared to in situ observations obtained in 2007, 2010 and 2012 during the COMOR scientific cruises supervised by Ifremer (Vigneau et al., 2001; Foucher, 2014) in three areas of the Bay of Seine. Simulated growth curves for each mesh of the model in these locations are plotted in Figure 11. The comparison reveals that the model fits the observed data and appears to correctly simulate the growth of scallops over several years. 


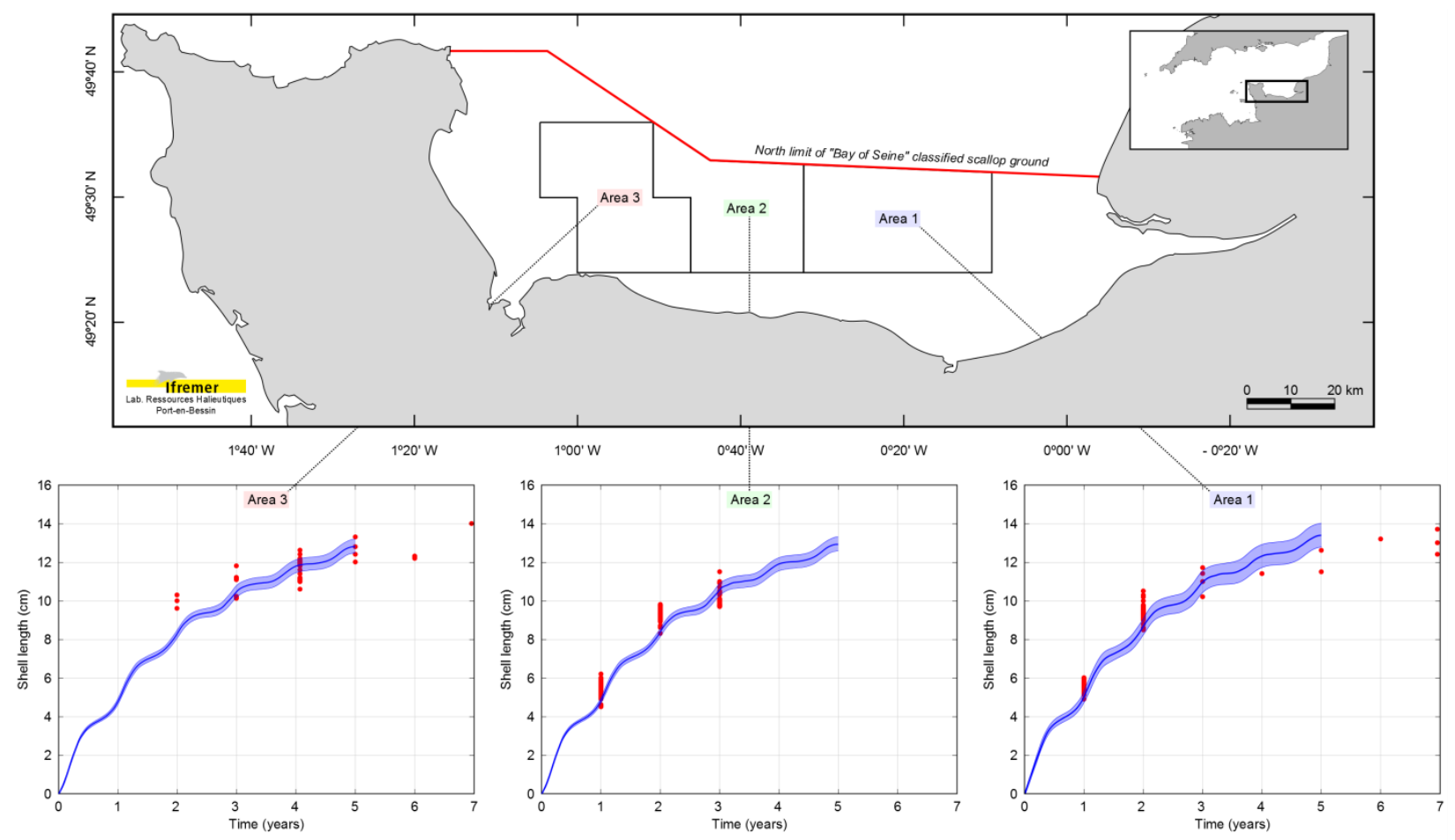

Figure 11. Evaluation of the modeled growth curves (blue lines) of an average individual in three locations of the Bay of Seine compared to in situ observations (red dots).

The spatial distribution of eggs released was calculated for each age class through the DEB model. Figure 11a shows the production of eggs by each age class in the Bay of Seine for a given year. The cumulative number of eggs released by each age class over time shows that the reproductive activity of two-year-old scallops (less than $0.2 \times 10^{6} \mathrm{eggs}^{-1}$ ) was five to ten times lower than for the older cohorts. The small difference between the amount of eggs spawned by six- and sevenyear-old individuals indicates a stabilization of the reproductive effort with the age. The simulation of the total amount of eggs spawned in the whole English Channel over seven years (Figure 11b) indicates that the inter-annual variability is low at the scale of the Channel. The average total number of eggs spawned per year was $1.7 \times 10^{11}$ for all the age-classes. As previously observed for growth, the production of eggs was maximal in the most productive areas and seemed to be linked to the food availability (Figure 12c).

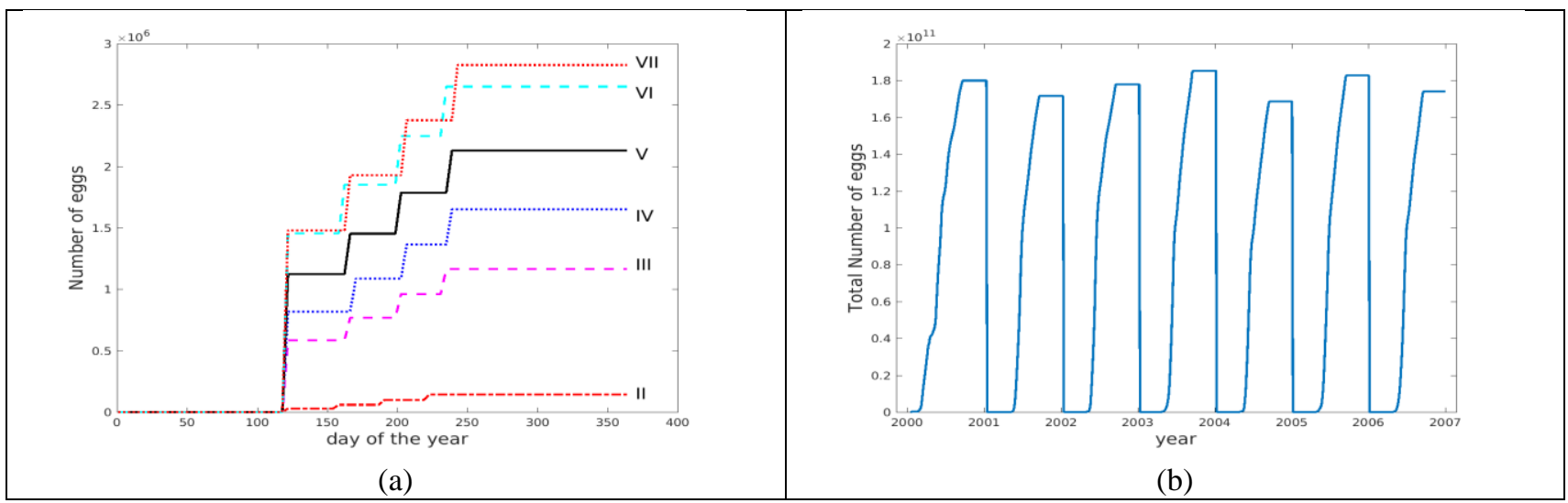




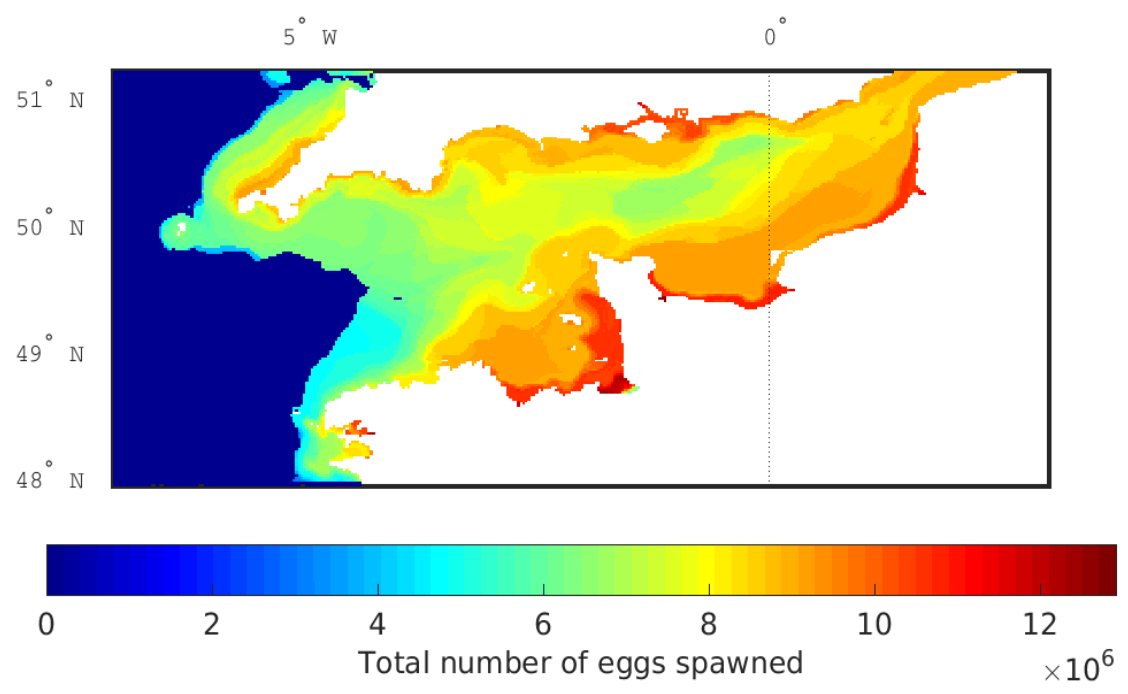

(c)

Figure 12. (a) Number of eggs spawned by each age class in the Bay of Seine $\left(0^{\circ} 48 \mathrm{~W}\right.$ and $\left.49^{\circ} 2 \mathrm{~N}\right)$ predicted for any given year; (b) Total number of eggs spawned in the English Channel from 2000 to 2006; (c) Spatial distribution of total number of eggs spawned for a given year.

\subsection{Simulating $P$. maximus distribution in the Channel: the role of the trophic environment}

The aim of this simulation was to improve the biological parameters of the population dynamic model from the ecophysiological model. In each mesh of the spatial grid, the number of eggs produced by each age-class (Figure 12c) was used as an input parameter of the population dynamics model. Because of the very low inter-annual variability in the production of eggs (in quantity and over space, see section 3.2.) emphasized by the model, an average spatial distribution was computed.

The model was run over 27 years and as for the case described in section 3.1, the population stabilized after 20 years of simulation (Figure 13). The simulated distribution shows higher densities near the coasts. A global reduction of density was observed in the whole Channel (Figure 12) compared to the previous case, with more realistic values than those obtained in the first experiment, although still relatively high (up to 1.3 ind. $\mathrm{m}^{-2}$ ). 

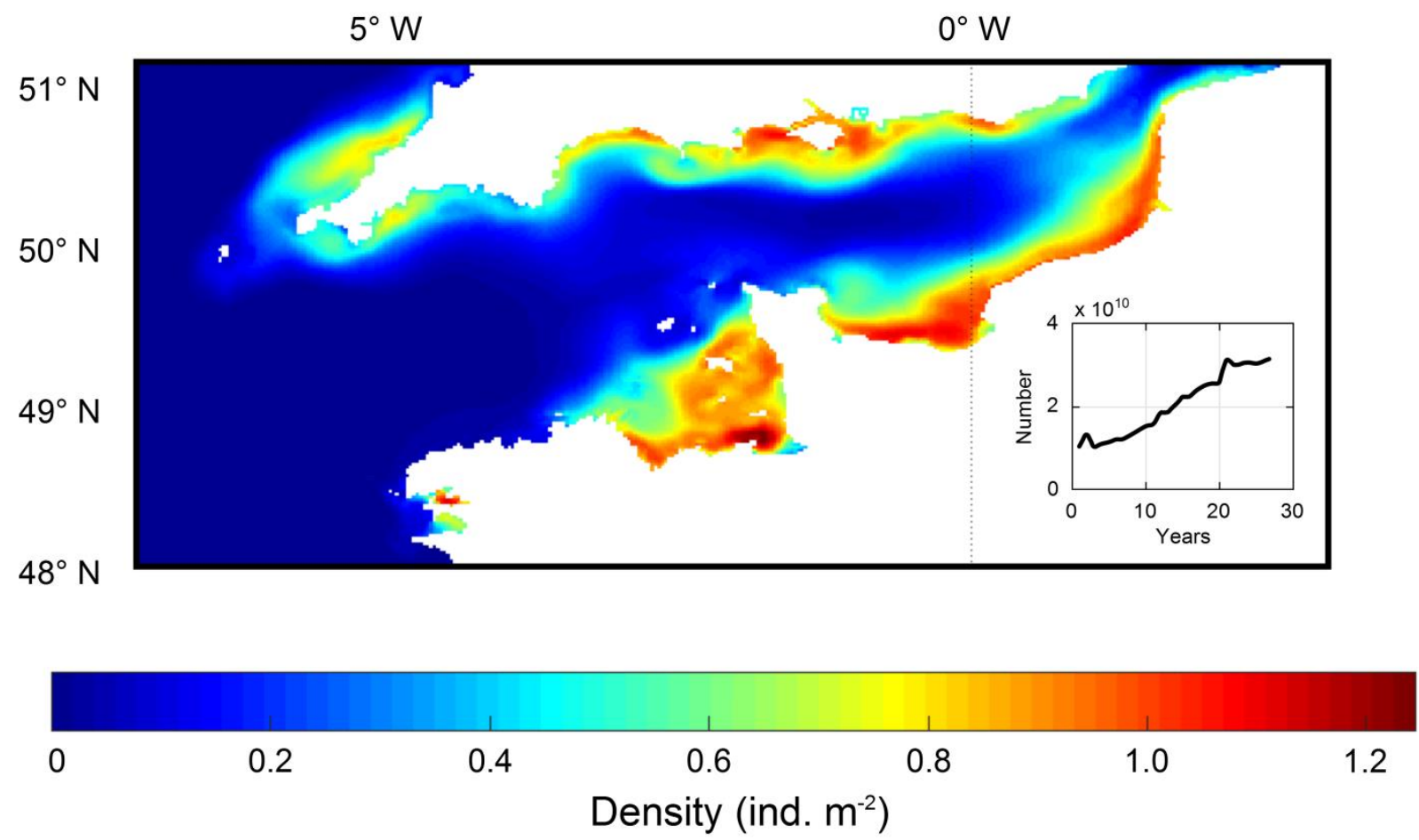

Figure 13. Distribution map of $P$. maximus after 27 years of simulation, represented as the total density of individuals from age class 2 to age class 12, when coupling the population model to the DEB model. The graph in the lower right corner illustrates the dynamic stabilization of the population over time (total number of all the individuals from age class 2 to age class 12 ).

\section{Discussion}

This study is the first to report realistic simulations of the distribution of the great scallop, $P$. maximus, in its main exploitation area, the English Channel. Savina and Ménesguen (2008) developed a similar approach in the Channel concerning the banded carpet shell, Paphia rhomboïdes. Its abundance was spatialized using a box model dividing the study area in 71 compartments, between which residual fluxes were used to simulate exchanges between populations through larval dispersion. The present model is based on the same conceptual approach for the population dynamic model, but the spatialization was ensured by a 3D hydrodynamic and biogeochemical model (ECO-MARS3D).

In the first step, the coupling of the hydrodynamic model MARS3D to the population dynamic model shows that the establishment of scallops is mainly driven by the dispersion of larvae and recruitment of the first year age class. In this case, the population model parameters mortality and fecundity are spatially homogeneous and adults are initially homogeneously distributed. Thus, the spatial variability is only due to hydrodynamic constraints on larval dispersion and spatially constrict the final settlement patterns. The local recruitment, defined as recruitment of the first age class, is the only variable parameter of the population model explaining the estimated distribution of adult scallops.

A recent study conducted by Nicolle et al. (2013) modeled larval dispersion of P. maximus in the English Channel, bringing new insights on the potential connectivity between different areas of the system. Depending on the meteorological and tidal conditions during spawning, a significant portion of the larvae born in the two main scallop beds along the French coast (the Bay of SaintBrieuc and the Bay of Seine) were retained in these areas and subjected to limited transport. Our simulations confirm such retention patterns with high densities emerging in these two bays (Figure 8). Nevertheless, simulated densities reached more than 1.8 ind. $\mathrm{m}^{-2}$ locally and remained around 1 ind. $\mathrm{m}^{-2}$ almost everywhere in the Channel, whereas stock assessments made each year in the Bay of Saint-Brieuc (Fifas and Caroff, 2014) and the Bay of Seine (Foucher, 2014), quantify the mean 
density to a maximum of 2 and 1.7 ind. $\mathrm{m}^{-2}$ respectively. The comparison with the existing scallop fisheries assessed suggests that some high density areas are correctly simulated, while mismatches in other areas (e.g. Bay of Mont-Saint-Michel, Isle of Wight) indicate a lack of information about some processes at this step of the simulation.

In order to account for the effect of trophic resources on the distribution of scallops in the Channel, an individual bioenergetic model was coupled to the ECO-MARS3D model. Results emphasized that the Bay of Saint-Brieuc, the Bay of Seine and the Dieppe area are among the most productive sites in terms of number of eggs released (Figure 12c). These model outputs are in accordance with results reported by Nicolle et al. (2013), which highlighted the crucial role of subpopulations from these bays to maintain the connectivity between sites in the English Channel. Our simulations indicate two other potential hotspots for egg production, located around the Isle of Wight (English coast) and in the Bay of Mont-Saint-Michel (French coast).

The physiological performances observed through the coupling of the individual bioenergetic model with the ECO-MARS3D model are likely reflective of the food availability (Figure 10) in the different areas of the English Channel. While temperature can explain variations observed in the physiological rates, food concentration is thought to influence the ultimate length (and weight) of individuals according to DEB theory (Kooijman, 2010). From our simulations (Figure 11), scallops reach their maximum length at the age of 7 years, as reported in the wild (Chauvaud et al., 2012). Spatial variability of food availability also influences the fecundity and the abundance of eggs, both of which are higher in the eastern Channel compared to the western Channel, revealing a higher amount of energy dedicated to reproduction on the eastern side. This would explain the low fecundity found in the deepest locations of the western area. Where depth typically exceeds $100 \mathrm{~m}$, food availability is low, and scallops exclusively rely on sinking organic particles (McCave, 1975; Bienfang, 1981; Smetacek, 1985), resulting in a relatively low amount of energetic reserves compared to enriched coastal areas. According to the DEB theory (Kooijman, 2010), the partition of mobilized energy between somatic growth and the reproduction buffer is constant for all individuals of the same species. In our model, fecundity is represented through the "release" of larvae from age class 2 to age class 7 . The cumulative number of larvae can reach $10^{7}$ when considering individuals of all age classes in each grid cell. Available data on fecundity in the literature indicate values ranging from $10^{7}$ to $2 \times 10^{7}$ eggs released per individual per spawning event for three-year-old scallops (Table 1 in Le Pennec et al., 2003). However, an accurate comparison with our simulation of the fecundity can hardly be made as only a fraction of the eggs produced develop into larvae.

Modeling this phenomenon is certainly one of the most difficult tasks in our simulation because the knowledge of the density of eggs released is not always correlated with the number of larvae. One key and difficult aspect also relies on the multivariate causes of the reproduction or fertilization success. For example, some theoretical and experimental studies (free-spawing invertebrates) on fertilization rates (Claereboudt 1999, Levitan 1992) show that the fertilization ratio can be highly dependent on the adult density, their aggregation pattern and also environmental conditions. The adult body size could also be synonymous with higher reproduction success but this size is often anti-correlated with the density of adults, leading to a decrease in the overall fertilization, as shown in the sea urchin Diadema antillarum Philippi (Levitan 1991). Nevertheless, to our knowledge no relationship between adult density and reproduction success exists in P. maximus (Boucher, 1990). In our simulations, all the eggs produced by an individual are first assumed to be fecund, but the number of larvae is then reduced by a high daily mortality rate $\left(0.5\right.$ day $^{-1}$ with respect to what is commonly encountered in the literature: 0.23 day $^{-1}$, Morgan, 1995) that implicitly takes into account the fertilization success, and the natural mortality during pelagic life stages and metamorphosis.

When coupling the population model to the DEB model, the spatial distribution of adult abundances shows a significant decrease in scallop densities across the whole Channel (Figure 13). The main changes are observed in the central part of the Channel where lower trophic resources induced 
lower fecundity.

Along the French coast, the main fishing areas in the Bay of Saint-Brieuc, the Bay of Seine and the Dieppe area are well represented through simulated high abundances of adults. However, other areas like the Bay of Mont-Saint-Michel seem to exhibit overestimated densities. Despite the existence of a small fishery in the Bay of Mont-Saint-Michel, catches remain far less than in the Bay of Saint-Brieuc and the Bay of Seine. Along the British coasts, densities may also be overestimated (Figure 2, 3, and 13). Around the Isle of Wight, simulations show a hotspot of scallops, but the absence of a scallop fishery (Figure 3) indicates that densities were overestimated in this area. As mentioned by Brand (2006), there are only a limited number of major areas within the geographical range of scallop species where the population is sufficiently abundant to support a commercial fishery. Such areas are usually widely separated by areas that are environmentally less suitable for the species (Brand, 2006).

A common characteristic of the two overestimated sites (Bay of Mont-Saint-Michel and Isle of Wight) is their high level of suspended particulate inorganic matter (SPIM) concentrations (Ménesguen and Gohin, 2006, Cayocca et al., 2008). Many studies have shown that high SPIM concentrations can affect the food assimilation efficiency of filter-feeders, largely due to food dilution by re-suspended inorganic particles (Barillé et al., 1997). Taking this effect into account in ecophysiological models improves simulations in highly turbid environments (Barillé et al., 2011; Saraiva et al. 2011) because food assimilation and associated energy is better simulated. As the Channel is not usually considered as a high turbidity environment, the bioenergetic model used in this study did not consider the effect of SPIM on food assimilation efficiency. Locally, in more turbid areas like the Isle of Wight or in the Bay of Mont-Saint-Michel, this could lead to an overestimation of food assimilation and of the individual physiological performance, i.e. fecundity (Figure 12c). Each year, the number of eggs spawned in these two areas is then also overestimated. Associated with hydrodynamic retentions that characterize these two bays (Ménesguen and Gohin, 2006, Cayocca et al. 2008), an annual self-recruitment is simulated, that increases the local population, year by year.

The absence of accurate data on the abundance of this species limits our conclusions. The particular interest of this approach lies in the integration of individual bioenergetic features to the population scale through the coupling of four models. In this context, the DEB theory provides a conceptual framework to quantitatively implement almost every metabolic process, with a set of estimated parameters for a given species. Thus, it would be possible to examine various physiological responses aside from growth and reproduction. Compared to the available information on the distribution of the great scallop at this regional scale, our modeling system successfully simulated the dispersion pattern of $P$. maximus.

The approach of this study could be improved by (i) detailing the physiological model, i.e. considering silt effect on feeding in coastal areas (Saraiva et al., 2011; Lavaud et al., 2014), (ii) integrating sea bottom sedimentary patterns (Vaslet et al., 1978; Bidegain et al., 2013) to better restrict recruitment to suitable areas with, for example, limited silt content and (iii) explicitly estimating the mortality rate from the DEB model according to the status of energetic reserves. Fishing mortality is not considered in our model, although implicitly through the total mortality. Explicit mortality by fishing helps to simulate fishing pressure and explore different fishing strategies. Finally, we could investigate the impact of environmental change in the English Channel (rising temperatures, changes in food resources patterns, etc.) on the physiology of the great scallop and further on its abundance and distribution.

The model presented here improves our knowledge on the distribution and stock dynamics of $P$. maximus and could be a useful tool to support new management rules based on rotating collection areas, as done for the Sea scallop Placopecten magellanicus in Northwestern Atlantic (Cheney, 2015; Munroe et al., 2015). 
Acknowledgements

This research was supported by the ANR project COMANCHE (ANR-2010-STRA-010-02). Authors thank the two anonymous reviewers whose comments contributed to a significant improvement of this article.

\section{Bibliography}

Abbes, R., 1991. Atlas des ressources et des pêches françaises dans les mers européennes, Edition Ouest-France, 99 pp.

Antoine, L., 1979. La croissance de la coquille Saint-Jacques Pecten maximus et ses variations en mer Celtique et en Manche. The growth of the great scallop Pecten maximus and its variations in the Celtic sea and the English Channel. Ph.D. thesis, Université de Brest, France.

Barillé, L., Prou, J., Heral, M. and Razet, D., 1997. Effects of high natural seston concentrations on the feeding, selection and absorption of the oyster Crassostrea gigas (Thunberg). Journal of Experimental Marine Biology and Ecology 212, 149-172.

Barillé, L., Lerouxel, A., Dutertre, M., Haure, J., Barillé, A.L., Pouvreau, S. and Alunno-Bruscia, M., 2011. Growth of the Pacific oyster (Crassostrea gigas) in a high-turbidity environment: Comparison of model simulations based on scope for growth and dynamic energy budgets. Journal of Sea Research 66, 392-402.

Bidegain, G., Bárcena, J.F. and Juanes, J.A., 2013. LARVAHS: Predicting clam larval dispersal and recruitment using habitat suitability-based particle tracking model. Ecological Modelling 268, 7892.

Bienfang, P. K., 1981. Sinking rates of heterogeneous, temperate phytoplankton populations. Journal of Plankton Research 3 (2), 235-253.

Boucher, J. and Dao, J.-C. 1990. Repeuplement et forçage du recrutement de la coquille SaintJacques (Pecten maximus). In L'homme et les ressources halieutiques, pp. 313-357. Ed. par J.-P. Troadec. IFREMER, Nantes. 375 pp.

Brand, A. R., 2006. Scallop ecology: distributions and behaviour. In Scallops: Biology, Ecology and Aquaculture. Vol. 35. Elsevier, Developments in aquaculture and fisheries science, Ch. 12, pp. 651-744.

Cabioch, L., 1968. Contribution à la connaissance des peuplements benthiques de la Manche Occidentale. Cahiers Biologie Marine IX (5), 720 pp.

Cabioch, L., Gentil, F., Glaçon, R. and Retière, C., 1977. Le macrobenthos des fonds meubles de la Manche : Distribution générale et écologie. In: Keegan B.F., Ceidigh P.O., Boaden P.J.S. (Editors), Biology of benthic organisms: $11^{\text {th }}$ European Symposium on Marine Biology, Galway, October 1976. Pergamon Press Oxford, UK, pp. 115-128.

Cayocca, F., Bassoullet, P., Le Hir, P., Jestin, H. and Cann, P., 2008. Sedimentary processes in a shellfish farming environment, Mont-Saint-Michel Bay, France. In: Kusuda, T., Yamanishi, H., Spearman, J., Gailani, J.Z. (Eds.), Sediment and Ecohydraulics: INTERCOH 2005. Elsevier, pp. 
Claereboudt, M., 1999. Fertilization success in spatially distributed populations of benthic freespawners: a simulation model. Ecological Modelling 121 (2), 221-233.

Condie, S.A., Mansbridge, J.V., Hart, A.M. and Andrewartha, J.R., 2006. Transport and recruitment of silver-lip pearl oyster larvae on Australia's North West Shelf. Journal of Shellfish Research 25 (1), 179-185.

Chauvaud, L., Patry, Y., Jolivet, A., Cam, E., Le Goff, C., Strand, Ø., Charrier, G., Thébault, J., Lazure, P., Gotthard, K. and Clavier, J., 2012. Variation in size and growth of the great scallop Pecten maximus along a latitudinal gradient. PLoSONE 7 (5), e37717.

Cheney T., 2015. Thinking outside the box: spatial closures and the Maine Sea scallop Scallop fishery. Book of abstracts. The 20th International Pectinid Workshop, 22nd-28th April 2015, Galway (Ireland), ISBN 978-8-9932622-8-3.

Cragg, S. M., and Crisp, D. J. 1991. The biology of scallop larvae. Development in aquaculture and fisheries science. In Scallops: Biology, Ecology and Aquaculture, pp. 75-132. Ed. by S. E. Shumway. Elsevier, New York. 1095 pp.

Cragg, S. M., 2006. Development, physiology, behaviour and ecology of scallop larvae. In Scallops: Biology, Ecology and Aquaculture. Vol. 35. Elsevier, Developments in aquaculture and fisheries science, Ch. 2, pp. 45-122.

Cugier, P., Ménesguen, A. and Guillaud, J.F., 2005. Three-dimensional (3D) ecological modelling of the Bay of Seine (English Channel, France). Journal of Sea Research 54(1), 104-124.

Dekshenieks, M.M., Hofmann, E.E., Klinck, J.M. and Powell, E.N., 2000. Quantifying the effects of environmental change on an oyster population: a modeling study. Estuaries 23 (5), 593-610.

Klinck, J.M., Hofmann, E.E., Powell, E.N. and Dekshenieks, M.M., 2002. Impact of channelization on oyster production: a hydrodynamic-oyster population model for Galveston Bay, Texas. Environmental Modeling Assessment 7, 273-289.

Ellien, C., Thiébaut, E., Dumas, F., Salomon, J.C. and Nival, P., 2004. A modelling study of the respective role of hydrodynamic processes and larval mortality on larval dispersal and recruitment of benthic invertebrates: example of Pectinaria koreni (Annelida: Polychaeta) in the Bay of Seine (English Channel). Journal of Plankton Research 26 (2), 117-132.

Fifas, S. and Caroff N., 2014. Gisement de coquilles Saint Jacques de la baie de Saint-Brieuc. Campagne 2014 d'évaluation directe (23/08 au 4/09/2014). Résultats et analyse. CRPMEM Bretagne - Comité Régional des Pêches Maritimes et des Elevages Marins de Bretagne, Ref. Ifremer - STH/LBH - SF - 14.013, 18p.

Foucher, E., 2014. Evaluation annuelle du stock de coquilles Saint-Jacques de la baie de Seine : résultats de la campagne COMOR $44 \quad(5$ au 22 juillet 2014) http://archimer.ifremer.fr/doc/00253/36430/.

Foucher, E. and Fifas, S., 2013. The French inshore King scallops (Pecten maximus) fisheries in the English Channel: recent trends on exploitation, regulations and stock assessment. Book of abstracts. 19th International Pectinid Workshop, Florianopolis (Brazil), 10th-16th April 2013. 
ICES, 2013. Report of the Scallop Assessment Working Group (WGScallop), 2-5 September 2013, Galway, Ireland. ICES CM 2013/ACOM:42. 81pp.

Gangnery, A., Bacher, C. and Buestel, D., 2004. Modelling oyster population dynamics in a Mediterranean coastal lagoon (Thau, France): sensitivity of marketable production to environmental conditions. Aquaculture 230: 323-347.

Gentil, F., 1976. Distribution des peuplements benthiques en baie de Seine. Ph.D. thesis, Université de Paris VI, France, 250 pp.

Holm, E., 1990. Effects of density-dependent mortality on the relationship between recruitment and larval settlement. Marine Ecological Progress Series 60: 141-146.

Holme, N.A., 1966. The bottom fauna of the English Channel. Part II. Journal of the Marine Biological Association of the United Kingdom 46, 401-493.

Kooijman, S.A.L.M., 2010. Dynamic Energy Budget theory for metabolic organization. Cambridge, UK, third edition. University Press.

Lavaud, R., Flye-Sainte-Marie, J., Jean, F., Emmery, A., Strand, Ø. and Kooijman, S.A.L.M., 2014. Feeding and energetics of the great scallop, Pecten maximus, through a DEB model. Journal of Sea Research 94, 5-18.

Lazure, P. and Dumas, F., 2008. An external-internal mode coupling for a 3D hydrodynamical model for applications at regional scale (MARS). Advances in Water Resources 31(2), 233-250.

Levitan, D., 1991. Influence of body size and population density on fertilization success and reproductive output in a free-spawning invertebrate. Biological Bulletin, 181 (2), 261-268.

Levitan, D. R., Sewell, M. A. and Chia, F.S., 1992. How distribution and abundance influence fertilization success in the sea urchin Strongylocentotus Franciscanus. Ecology, 73: 248-254.

Le Pennec, M., Paugam, A. and Le Pennec, G., 2003. The pelagic life of the pectinid Pecten maximus - a review. Journal of Marine Science 60 (2), 211-233.

Mason, J., 1957. The age and growth of the scallop Pecten maximus in Manx Waters. Journal of the Marine Biological Association of the United Kingdom 36-03, 473-492.

Mason, J., 1983. Scallop and Queen fisheries in the British Isles. Fishing News Books Ltd, Surrey, UK: 143 pp.

McArdle, B.H., Hewitt, J.E. and Thrush, S.F., 1997. Pattern from process: it is not as easy as it looks. Journal of Experimental Marine Biology and Ecology 216, 229-242.

McCave, I., 1975. Vertical flux of particles in the ocean. Deep Sea Research and Oceanographic Abstracts 22 (7), 491-502.

Ménesguen, A. and Gohin F., 2006. Observation and modelling of natural retention structures in the English Channel. Journal of Marine Systems 63, 244-256.

Mileikovsky, S.A., 1973. Speed of active movement of pelagic larvae of marine bottom 
invertebrates and their ability to regulate their vertical position. Marine Biology 23, 11-17.

Munroe D., Hart D.R., Shank B., Haidvogel D., Wang Z., Powel E.N., Klinck J. and Hofmann E., 2015. Managing the supply side: larval dispersal from rotating closures in the Atlantic Sea Scallop (Placopecten magellanicus) fishery. Book of abstracts. The 20th International Pectinid Workshop, 22nd-28th April 2015, Galway (Ireland), ISBN 978-8-9932622-8-3.

Nicolle, A., Dumas, F., Foveau, A., Foucher, E. and Thiébaut, E., 2013. Modelling larval dispersal of the king scallop (Pecten maximus) in the English Channel: examples from the bay of SaintBrieuc and the bay of Seine. Ocean Dynamics 63 (6), 661-678.

Passy, P., Le Gendre, R., Garnier, J., Cugier, P., Callens, J., Paris, F., Billen, G. Riou, P. and Romero, E., 2016. Eutrophication modelling chain for improved management strategies to prevent algal blooms in the Bay of Seine. Marine Ecology Progress Series 543, 107-125.

Pitel, M., Berthou, P. and Fifas, S., 2001. Ecodredge (1999-2001) report. 1-Dredge design and fisheries. Rapport Ifremer, $95 \mathrm{pp}$.

Possingham, H.P. and Roughgarden, J., 1990. Spatial population dynamics of a marine organism with a complex life cycle. Ecology 71 (3), 973-985.

Retière, C., 1979. Contribution à la connaissance des peuplements benthiques du Golfe NormandBreton. Ph.D. thesis, Université de Rennes, France, 421 pp.

Romero E., Garnier J., Lassaletta L., Billen G., Le Gendre R., Riou P. and Cugier P., 2013. Largescale patterns of river inputs in southwestern Europe: seasonal and interannual variations and potential eutrophication effects at the coastal zone. Biogeochemistry, 113 (1-3), 481-505.

Salomon, J.P. and Breton, M., 1993. An atlas of long-term currents in the Channel. Oceanologica Acta 16 (5-6): 439-448.

Saraiva, S., van der Meer, J., Kooijman, S.A.L.M. and Sousa, T., 2011. Modelling feeding processes in bivalves: A mechanistic approach. Ecological Modelling 222 (3), 514-523.

Savina, M. and Ménesguen, A., 2008. A deterministic population dynamics model to study the distribution of a benthic bivalve with planktonic larvae Paphia rhomboïdes in the English Channel (NW Europe). Journal of Marine Systems 70 (1), 63-76.

Smetacek, V. S., 1985. Role of sinking in diatom life-history cycles: ecological, evolutionary and geological significance. Marine Biology 84 (3), 239-251.

Solidoro, C., Melaku Canu, D. and Rossi, R., 2003. Ecological and economic considerations on fishing and rearing of Tapes phillipinarum in the lagoon of Venice. Ecological Modelling 170, 303318.

Strohmeier, T., Strand, Ø. and Cranford, P., 2009. Clearance rates of the great scallop Pecten maximus and blue mussel Mytilus edulis at low natural seston concentrations. Marine Biology 156 (9), 1781-1795.

Thompson, R. J. and MacDonald, B. A., 2006. Physiological integrations and energy partitioning. In Scallops: Biology, Ecology and Aquaculture. Vol. 35. Elsevier, Developments in aquaculture and fisheries science, Ch. 8, pp. 493-520. 
Tully, O., Hervas, A., Berry, A., Harnett, M., Sutton, G., O'Keeffe, E. and Hickey, J., 2006. Monitoring and assessment of scallops off the South East coast of Ireland. Fisheries resource series, Bord lascaigh Mhara (Irish Fisheries Board), Dun Laoghaire, Ireland, 5, 20 pp.

Vanhoutte-Brunier A., Fernand L., Ménesguen A., Lyons S., Gohin F. and Cugier P., 2008. Modelling the Karenia mikimotoi bloom that occurred in the western English Channel during summer 2003. Ecological Modelling 210 (4), 351-376.

Vaslet D., Larsonneur C. and Auffret J.P., 1978. Carte des sédiments superficiels de la Manche, BRGM, France, carte à 1:500 000.

Vigneau, J., Fifas, S. and Foucher, E., 2001. Les campagnes d'évaluation du stock de coquilles Saint-Jacques en Manche orientale : méthodologie et estimation des indices d'abondance. http://archimer.ifremer.fr/doc/00000/6550/.

Young, E.F., Bigg, G.R., Grant, A., Walker, P. and Brown, J., 1998. A modelling study of environmental influences on bivalve settlement in the Wash, England. Marine Ecological Progress Series 172, 197-214.

Appendix 1. Equations computing biological processes for reproduction, larval life and benthic life in the population dynamic model (adapted from Savina and Ménesguen, 2008).

\section{Spawning:}

For $\mathrm{t}_{1}<\mathrm{t}<\mathrm{t}_{2} N O(t)=\sum_{c=c_{a}}^{c_{b}} \operatorname{frep}(t) X_{c}(t) N_{t o t}$, where $\quad \operatorname{frep}(t)=\frac{1}{\sigma \sqrt{2 \pi}} \exp -\frac{\left(t-t_{0}\right)^{2}}{2 \sigma^{2}}$

$N O(\mathrm{t}):$ total number of eggs produced at time $\mathrm{t}$ per $\mathrm{m}^{2}$ of substrate;

$\mathrm{t}_{1}, \mathrm{t}_{2}$ : beginning and ending dates of the spawning period;

$X_{c}(\mathrm{t})$ : abundance of adults of age class $\mathrm{c}$ at time $\mathrm{t}\left(\right.$ ind. $\mathrm{m}^{-2}$ );

$\mathrm{c}_{\mathrm{a}}$ : first mature age class;

$\mathrm{c}_{\mathrm{b}}$ : last mature age class;

frep $(\mathrm{t})$ : spawning distribution function throughout the reproduction period;

$N_{\text {tot }}$ : Total number of eggs produced by one individual over the spawning period;

$\mathrm{t}_{0}$ : mean spawning date $\left(\mathrm{t}_{1}+\mathrm{t}_{2}\right) / 2$

$\sigma:$ standard deviation of spawning period.

\section{Larval life:}

Larvae are distributed into 10 age classes of 3 days each

$$
\frac{d X_{l c}(t)}{d t}=r L_{c}(t)-v L_{c}(t)-X_{l c}(t) \cdot m L-X_{l c}(t) \cdot \frac{F i l t}{h}+F s e d_{l c}
$$

$\mathrm{X}_{\mathrm{lc}}(\mathrm{t})$ : larval abundance in the water column at time $\mathrm{t}\left(\right.$ ind. $\mathrm{m}^{-3}$ );

$\mathrm{mL}$ : larval mortality rate $\left(\mathrm{d}^{-1}\right)$;

$\mathrm{h}:$ thickness of the water layer considered $(\mathrm{m})$

Filt : global filtration rate of benthos $\left(\mathrm{m}^{3} \mathrm{~m}^{-2} \mathrm{~d}^{-1}\right)$ depending on the abundance of adults and the individual filtration rate;

Aging:

- $I^{\text {st }}$ age class:

Arrival of young larvae from adults spawning in the bottom layer of the water column

$$
r L_{1}=\frac{N O(t)}{h}
$$


- General case:

The transfer of individuals from one age class to another occurs every three days during one time step of computation, it begins from the oldest age class and goes on to the youngest one

Departure from the age class c:

$$
\text { ift }=0 \bmod (3)
$$

$$
v L_{c}(t)=\frac{-X_{l c}(t)}{d t}
$$

$v L_{c}:$ rate of departure of the larvae in class c;

Arrival in the age class $c$ :

$$
r L_{c}(t)=\frac{-X_{l c-1}(t)}{d t}
$$

$r L_{c}$ : rate of arrival of the larvae in class c;

otherwise:

$$
r L_{l c}=0 \text { and } v L_{l c}=0
$$

Larval sedimentation on the bottom (in the bottom water layer):

if the age class is higher or equal to 5 (i.e. larvae have more than 15 days) and $\mathrm{V}_{\text {cur }}<\mathrm{V}_{\text {crit }}$

$$
\operatorname{Fsed}_{l c}=-X_{l c}(t) \cdot \frac{\operatorname{Vsed}_{l c}}{h}
$$

Vsed $_{l c}$ : larval sedimentation velocity for larvae of age class c;

Fsed $_{l c}$ : sedimentation rate of larvae of age class c;

$\mathrm{V}_{\text {cur: }}$ instantaneous current velocity;

$\mathrm{V}_{\text {crit }}$ : critical velocity above which larval sedimentation is impossible;

otherwise:

$$
\text { Fsed }_{l c}=0 \text {. }
$$

\section{Benthic life:}

Adults are distributed into 12 age classes of 1 year

$$
\frac{d X_{c}(t)}{d t}=r A(t)-v A(t)-X_{c}(t) \cdot\left(m_{c}+m_{c d} \cdot \sum_{i=2}^{12} X_{i}(t)\right)
$$

$X_{c}(\mathrm{t})$ : abundance of adults of age class c at time $\mathrm{t}$ (ind. $\mathrm{m}^{-2}$ );

$m_{c}$ : mortality of adults depending on age $\left(\right.$ day $\left.^{-1}\right)$

$m_{c d}$ : density dependence mortality (ind. ${ }^{-1} \mathrm{~m}^{2}$ day $^{-1}$ )

Aging:

- $\quad$ 1st age class recruitment

if $\mathrm{V}_{\text {cur }}<\mathrm{V}_{\text {crit }}$ :

$$
r A_{1}(t)=\sum_{i=c}^{d} X_{l i}(t) \cdot \operatorname{Vsed}_{l i}
$$

otherwise: 


$$
r A_{1}(t)=0
$$

$\mathrm{X}_{\mathrm{li}}(\mathrm{t})$ : larval abundance of age class $\mathrm{i}$ in the bottom water layer at time $\mathrm{t}$;

Vsed $_{l i}$ : larval sedimentation velocity for larvae of class age $\mathrm{i}$;

c: age class from which larvae start to have a downward motion;

d: last larvae age class;

$\mathrm{V}_{\text {cur }}$ : instantaneous current velocity;

$\mathrm{V}_{\text {crit }}$ : critical velocity above which larval sedimentation is impossible;

\section{- General case}

The transfer of individuals from one age class to another takes place every year during one computational time step. It starts from the oldest age class and goes on to the youngest one. It occurs before the recruitment period in order to avoid numerical dispersion (otherwise part of the newly recruited individuals could be transferred directly in the following age class).

$$
t_{t}=t_{0}-3 . \sigma_{T}
$$

if $\mathrm{t}=\mathrm{t}_{\mathrm{t}} \bmod (365)$

Departure from the age class $c($ for $c=1$ to 12$)$ :

$$
v A_{c}(t)=\frac{-X_{c}(t)}{d t}
$$

Arrival in the class age c (for $c=2$ to 12$):$

$$
r A_{c}(t)=\frac{X_{c-1}(t)}{d t}
$$

Otherwise:

$$
v A_{c}(\mathrm{t})=0 \text { and } r A_{c}(\mathrm{t})=0
$$

\begin{tabular}{|c|c|c|c|c|}
\hline Parameters & Comments & Value & Unit & References \\
\hline$N_{t o t}$ & $\begin{array}{l}\text { Total number of eggs spawned by scallops } \\
\text { of age greater than } 2 \text { years }\end{array}$ & $1.10^{6}$ & & Le Pennec et al., 2003 \\
\hline $\mathrm{t}_{1}, \mathrm{t}_{2}$ & $\begin{array}{l}\text { Beginning and ending date of the spawning } \\
\text { period }\end{array}$ & 180,200 & $\begin{array}{l}\text { Julian } \\
\text { day }\end{array}$ & This study. \\
\hline$\sigma$ & Standard deviation of the spawning period & 15 & day & \\
\hline$m L$ & Larval mortality & 0.5 & day $^{-1}$ & $\begin{array}{l}\text { Savina and Ménesguen, } \\
2008\end{array}$ \\
\hline Filt & Global filtration rate of benthos & 25 & $\mathrm{~L} \mathrm{~h}^{-1}$ & $\begin{array}{l}\text { Adapted from clearance rate } \\
\text { (Strohmeier, 2009) }\end{array}$ \\
\hline Vsed $_{l c}$ & Larval sedimentation velocity & 0.0001 & $\mathrm{~m} \mathrm{~s}^{-1}$ & $\begin{array}{l}\text { Mileikovsy, } 1973 \text { Cragg and } \\
\text { Crisp, } 1991\end{array}$ \\
\hline$m_{c}$ & $\begin{array}{l}\text { Exponential mortality law depending on } \\
\text { age: } \exp (-\alpha t)+\epsilon\end{array}$ & $\begin{array}{c}A=0.5 \\
\alpha=0.0025 \\
\epsilon=0.04\end{array}$ & days $^{-1}$ & $\begin{array}{l}\text { Adapted from Savina and } \\
\text { Ménesguen, } 2008\end{array}$ \\
\hline$m_{c d}$ & Density dependent mortality & $\mathrm{mc} / 100$ & $\begin{array}{ll}\text { ind. }^{-1} & \mathrm{~m}^{2} \\
\text { day }^{-1} & \end{array}$ & Calibration \\
\hline $\mathrm{V}_{\text {crit }}$ & $\begin{array}{l}\text { Bottom current velocity above which larval } \\
\text { sedimentation is impossible }\end{array}$ & 1 & $\mathrm{~m} \mathrm{~s}^{-1}$ & $\begin{array}{lrr}\text { Adapted from bottom shear } \\
\text { stress } & \text { Savina } & \text { and } \\
\end{array}$ \\
\hline
\end{tabular}

$t_{t}:$ transfer date;

$\mathrm{t}_{0}$ : average anniversary date of the recruitment for the cohort;

$\sigma$ : standard deviation of spawning period.

Appendix 2: List of biological parameters of the population dynamic model 


\begin{tabular}{|l|l|l|l|l|}
\hline & \multicolumn{1}{|c|}{} & & Ménesguen, 2008 \\
\hline$X_{k}$ & $\begin{array}{l}\text { Half saturation coefficient for food } \\
\text { assimilation function of the scallop DEB } \\
\text { model }\end{array}$ & $\begin{array}{l}\mu \mathrm{g} \mathrm{L}^{-1} \\
\text { Chl- } a\end{array}$ & Calibration \\
\hline
\end{tabular}

